\title{
DEMOCRACIA ENCLAUSURADA: um debate crítico sobre a democracia representativa contemporânea
}

\section{Manoel Adam Lacayo Valente}

Curso: Mestrado em Sociologia

Data de defesa da dissertação: 8 de junho de 2004

Orientador: Prof ${ }^{a} D^{a}$ Maria Francisca Pinheiro Coelho

\section{Resumo}

Esta dissertação tem como objetos de reflexão a democracia representativa contemporânea, a crise de legitimidade que sobre ela se abate e a emergência de um novo paradigma de democracia combinada, que contempla a agregação da dimensão participativa à concepção tradicional de democracia representativa.

O estudo examina as principais correntes de pensamento que teorizam sobre a natureza da democracia contemporânea, analisa os fatores que contribuíram para configurar a crise da democracia representativa e procura sistematizar, em termos teóricos, uma concepção viável de democracia para sociedades complexas.

A reflexão fundamental que se faz presente ao longo da dissertação é a que põe em xeque a concepção minimalista de democracia que restringe o regime democrático à competição eleitoral. O trabalho dissertativo aponta para a insuficiência dessa concepção e apresenta, a partir do pensamento de estudiosos acadêmicos modernos, um paradigma de democracia que transcende os limites da "democracia eleitoral" e que incorpora elementos participativos substanciais, o que pode vir a caracterizar, por sua singularidade, uma "quarta onda de democratização". Pelo lado empírico, os dados coligidos no Relatório de Desenvolvimento Humano de 2002, 
elaborado pelo Programa das Nações Unidas para o Desenvolvimento (PNUD), cujo título é "Aprofundar a Democracia num Mundo Fragmentado", ratificam as idéias analisadas neste trabalho relacionadas à insuficiência democrática da democracia meramente eleitoral.

Palavras-chave: democracia; democracia representativa; democracia participativa; democracia deliberativa; democracia minimalista; crise da democracia. 